\title{
Environmental Effects of Aquifer Overexploitation: A Case Study in the Highlands of Mexico
}

\author{
MARIA VICENTA ESTELLER* \\ CARLOS DIAZ-DELGADO \\ Centro Interamericano de Recursos del Agua \\ Facultad de Ingenieria, Universidad Autonoma del Estado de \\ Mexico \\ Cerro Coatepec, S/N. C.U. 50130 Toluca (Estado de Mexico) \\ Mexico
}

ABSTRACT / There are several environmental processes occurring under aquifer overexploitation conditions. These processes include groundwater table decline, subsidence, attenuation and drying of springs, decrease of river flow, and increased pollution vulnerability, among others processes. Some of these effects have been observed on the Upper Basin of the Lerma River. The Lerma River begins in the SE of the Valley of Toluca at 2,600 $\mathrm{m}$ asl, in the wetland known as Lagoons of Almoloya del Río. This wetland is made up of a group of lagoons, which are an important aquatic system from an environmental point of view. The water inflow of this wetland is a discharge of springs, which occur between the fractured volcanic material of the mountain range and granular volcanic-continental deposits of the Valley of Toluca aquifer. The intensive exploitation of the Valley of Toluca aquifer to supply urban and industrial water to Mexico City and Toluca began in 1950 and is responsible for a steady decline of piezometric levels of $1-3.5 \mathrm{~m} / \mathrm{yr}$. Other effects of this exploitation - the drying of the wetland, the decrease of river flow and the land subsidencecaused serious ecological and social impacts. The authorities declared this aquifer as overexploited in order to reduce the exploitation and preserve the availability of water resources in this important region.
The environmental impacts of aquifer overexploitation have been observed in numerous places around the world (Llamas 1992). In these places, the adverse consequences have been proven, one of the most important being the desiccation of wetlands and rivers, with subsequent loss of the aquatic ecosystem, which is of great ecological value due to its wide biodiversity (Rodriguez-Estrella and Lopez-Bermudez 1992, Martinez-Alfaro and others 1992, Cruickshank 1995). Other effects are a decline in the groundwater level, subsidence, the drying-up of springs, a decrease in river flow and a deterioration of water quality, among others (Martinelli and others 1998, Celik and Afsin 1998, Scott and others 1999).

The region of the Upper Course of the Lerma River (Central Mexico) is a representative example of the overexploitation problem. The Upper Course of the Lerma River, giving rise to the Upper Basin of the Lerma River, is situated in an area known as the Mexican Highlands (Figure 1). This area is an important center for industrial and agricultural activity, with a high population density and enormous demands for

KEY WORDS: Water resources exploitation; Water table decline; Dimi-
nution of river flow; Wetland; Ecological impact; Social
impact

*Author to whom correspondence should be addressed; e-mail: esteller@coatepec.uaemex.mx water, which are being met almost exclusively from groundwater. Moreover, added to this problem, is the exportation of groundwater from this basin to Mexico City, for part of the city's water supply. This water exportation to Mexico City is done at a rate of 14 $\mathrm{m}^{3} / \mathrm{sec}$, a volume taken from the aquifers of the valleys of Toluca and Atlacomulco-Ixtlahuaca, both located in the Upper Basin of the Lerma River. Of these two valleys, the one subject to greater exploitation is the Valley of Toluca (CCRECRL 1993).

The lagoons of Almoloya del Rio are located in the Valley of Toluca (SE sector), giving rise to the Lerma River, and make up the only natural wetland of the Upper Basin of the Lerma River, situated at an altitude of 2237-2600 $\mathrm{m}$ asl.

These lagoons have, for many centuries, represented a way of life for the inhabitants of the area as their activities were based on hunting, fishing, and gathering of aquatic flora and fauna. On the other hand, this area is an important natural reserve, because of its biodiversity (Albores 1995, CCRECRL 1997, Boehm and Sandoval 1999).

The deterioration of the ecosystem of the Lagoons of Almoloya del Rio is related to the exploitation of the groundwater resources at rates higher than the natural recharge, giving rise to the overexploitation of the Valley of Toluca aquifer.

This paper aims to establish, in the most pragmatic possible way, the effects of the overexploitation of the 


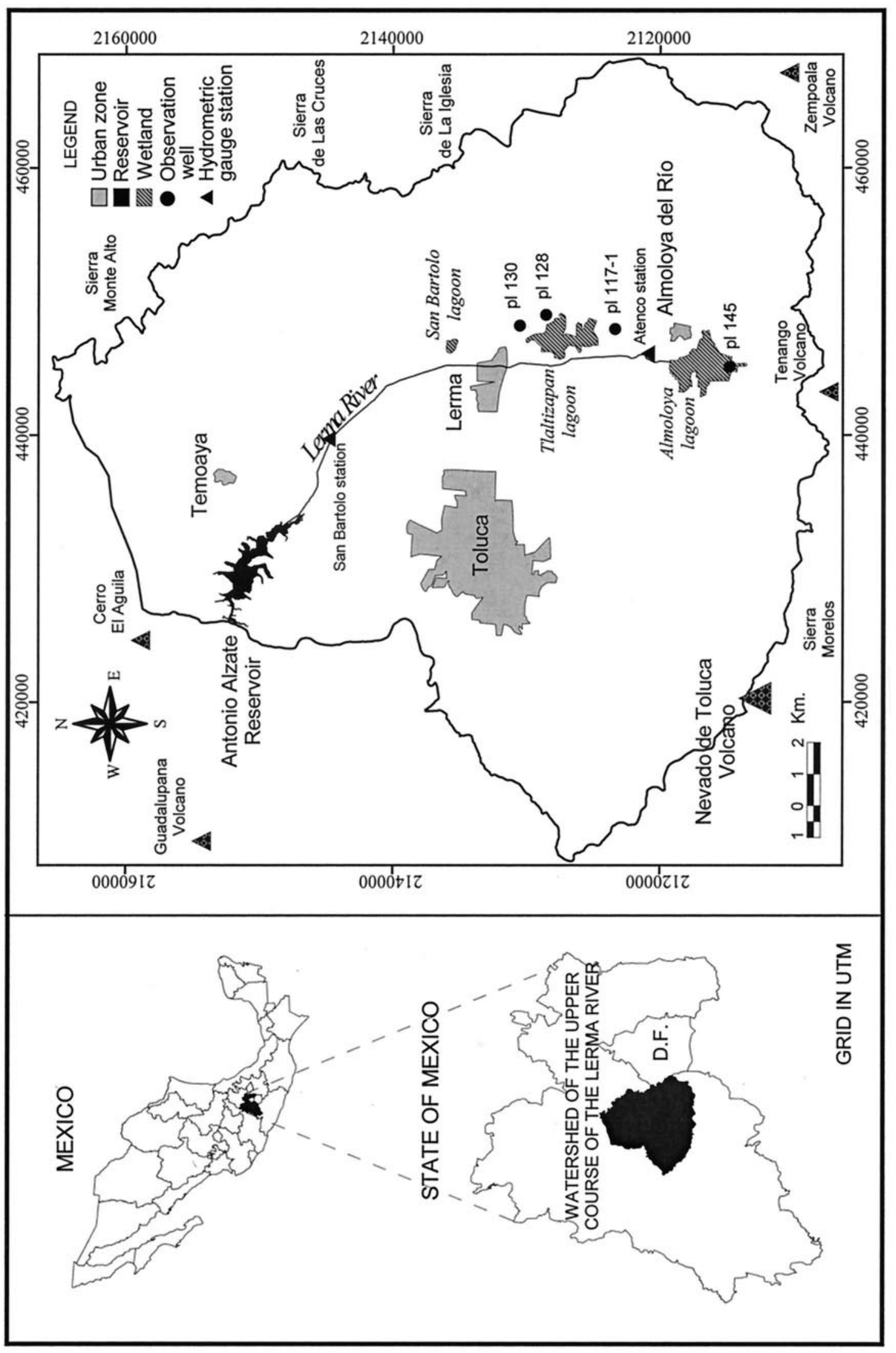


aquifer on the wetland, on the Lerma River, as well as on the land subsidence.

\section{Materials and Methods}

One of the main initial stages for analysis of the basin's functioning is a physiographic understanding of the basin. In this paper, the physiographic characteristics of the watershed were obtained through digital elevation model (DEM) processing with a resolution of $90 \mathrm{~m}$. The information source corresponds to the contours on the geographic map of the State of Mexico (IGECEM 1995). The DEM of the Upper Course of the Lerma River, where the Valley of Toluca is located, was produced through GIS Arc/INFO software, ver. 7.1.2 [Triangular Irregular Network (TIN) module] and ArcVIEW 3.0a.

For the study of the piezometric evolution of the Valley of Toluca aquifer data from the existing piezometric monitoring network, 66 observation wells, run by the National Water Commission [Comisión Nacional del Agua (CNA) ], were used. In addition, hydrometric data from the Atenco and San Bartolo gauge stations, located in the wetland area, also operated by the CNA, were used.

In order to determine the flow of the Lerma River up to the limit of the José Antonio Alzate reservoir, a hydrological estimation was carried out, based on the data from the three hydrometric gauge stations that are found in the basin above the reservoir, as there is no one station that is pertinent for the whole tributary area. The time period for records used corresponds covered 1974-1990.

The evolution over time of the wetland surface area was based on aerial photographs (1970 flight, scale 1:25,000; 1971 flight, scale 1:10,000; 1989 flight, scale 1:5000; and 1995 flight, scale 1:5000) and orthophotos (1983 flight, scale 1:10,000; 1989 flight, scale 1:5000; and 1995 flight, scale 1:5000).

Field surveys were also carried out to locate and geoposition cracks and differential collapses of the land.

\section{Study Area}

\section{Geographic-Geologic Framework}

The Valley of Toluca is located in the central area of Mexico, more specifically in the central zone of the State of Mexico, and is one of the highest in elevation in the Mexican Highlands. The Valley of Toluca, located in the Upper Course of the Lerma River (Figure 1), has an average elevation of $2570 \mathrm{~m}$, up to the José Antonio Alzate reservoir, which is the first receiving body for water coming from the Lerma River. At ap- proximately $9 \mathrm{~km}$ downstream from the dam, at an altitude of $2570 \mathrm{~m}$, the Upper Course of the Lerma River ends where the tectonic steps of the Valley of Atlacomulco-Ixtlahuaca descend (CCRECRL 1997).

The Valley of Toluca covers an area of around 700 $\mathrm{km}^{2}$, with the main axis running north-south with a length of almost $35 \mathrm{~km}$, and the shorter axis running east-west about $20 \mathrm{~km}$. The northern borders are the Guadalupana volcano, the Cerro El Aguila, and the Sierra Monte Alto; to the south the Tenango and Zempoala volcanoes; to the east the Sierra de Las Cruces and La Iglesia; and to the west the Nevado de Toluca and Sierra Morelos. Figure 2 shows a relief map of the watershed of the Upper Course of the Lerma River. The energy in the relief shown in the southern portion should be noted, from the Nevado de Toluca volcano, and on the eastern side, due to the presence of the Sierra de Las Cruces.

The Upper Course of the Lerma River is located in tropical latitudes (parallels $19^{\circ} 05^{\prime}$ and $19^{\circ} 50^{\prime} \mathrm{N}$ ), but its high altitude, as well as the adjacent mountains (Sierra de Las Cruces and the Nevado de Toluca), and without continental climate characteristics give rise to a more temperate climate-semicold and cold. The average monthly temperature varies between $5^{\circ} \mathrm{C}$ (at places above $3000 \mathrm{~m}$ in altitude) and $20^{\circ} \mathrm{C}$ (areas situated in the valley). The rainy season starts in the mid-May and lasts until mid-October. Average annual precipitation is highest on the sides of the Nevado de Toluca, where isohyets of $1200 \mathrm{~mm}$ can be found, decreasing towards the valley with averages of $900 \mathrm{~mm}$. The highest records of precipitation come in the month of June, after this month there is a lack of rain, which generally coincides with the month of August; this period is called the mid-summer draught. Using Köppen's climatic classification (Miller 1982), the Valley of Toluca presents a C(w2) (w)bi (g) climate, which corresponds to a subhumid temperate climate, with a long summer, winter rain of less than $5 \%$, isothermal and maximum temperatures before the summer solstice.

The area under study is located specifically in the physiographic province called the Neovolcanic Transmexican Axis (Deman 1976), an area made up of a strip of volcanic material, calcoalkaline type, whose age dates it in the Upper Cenozoic. The lithological sequence is made up of various types of tertiary volcanic rocks, mainly basalt and andesite, as well as pyroclastic matter and breaches, abundant in the mountain ranges surrounding the valley (Figure 3). Lacustrine and alluvial sediments can be identified in the valley and are interspersed with clastic deposits of volcanic origin. The age assigned to these deposits is Late Pliocene-Quaternary (Honorio and Hernandez 1982, Herrera and Sánchez 1994). 


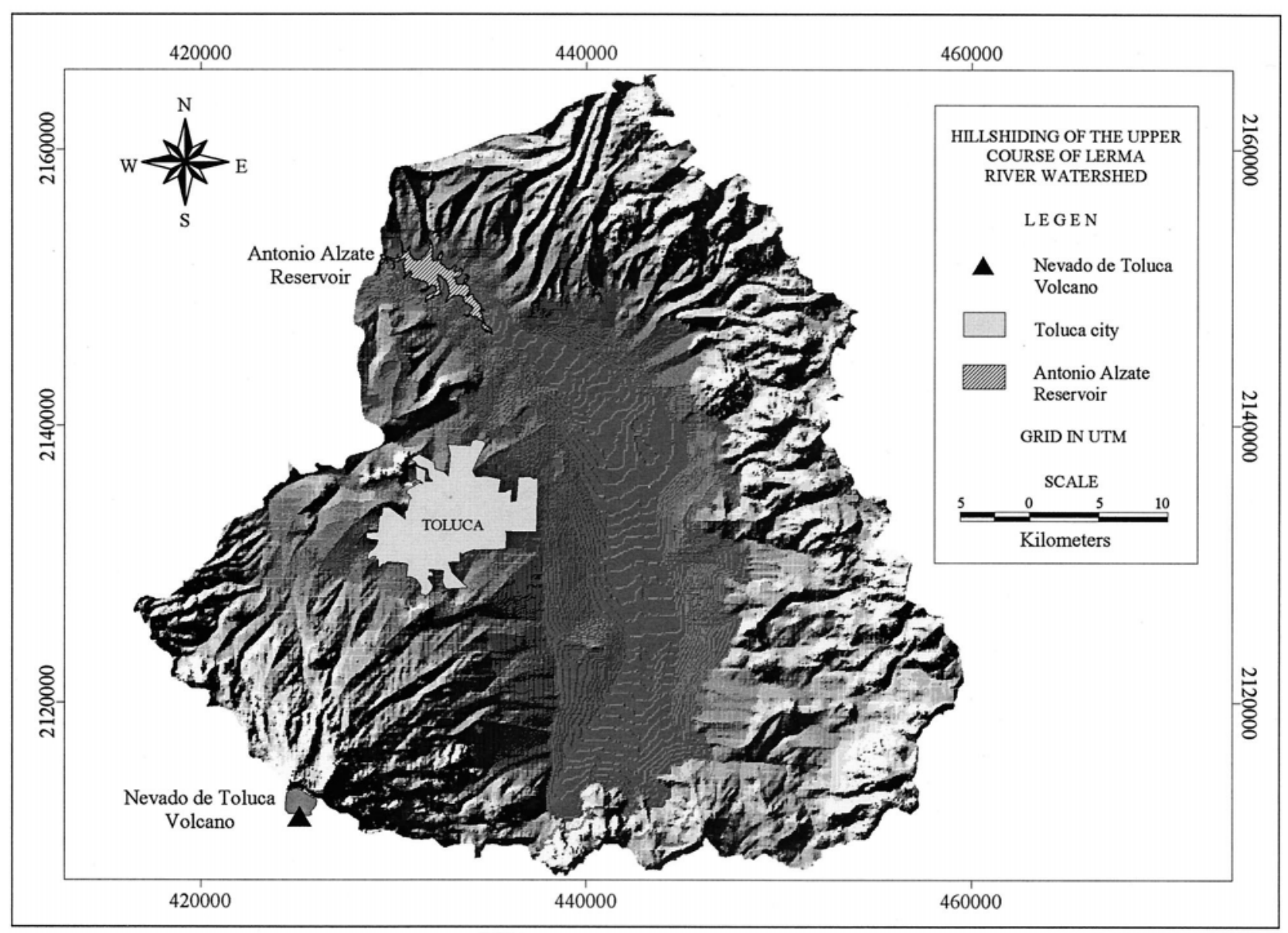

Figure 2. Relief map of the watershed of the Upper Course of the Lerma River.

\section{Surface hydrology and hydrogeology}

The data obtained from the DEM allowed the definition of the main physiographic features of the Upper Course of the Lerma River. Table 1 shows the results obtained in estimating these features.

For the period 1974-1990, the annual volume of Lerma River for a dry year (1982-1983) was $98 \mathrm{hm}^{3} / \mathrm{yr}$, for a wet year (1976-1977) $267 \mathrm{hm}^{3} / \mathrm{yr}$, and for an average year $171 \mathrm{hm}^{3} / \mathrm{yr}$, with minimum volume in March and maximum in September (Figure 4).

With reference to the hydrogeology, it must be pointed out that two aquifers can be defined in the basin, the border aquifer, made up of fractured volcanic rocks, which form the mountainous elevations, and the valley aquifer, formed by granular materials of volcanic-sedimentary origin. The clastic aquifer, known as the aquifer of the Valley of Toluca, is made up of material which is noticeably heterometric, with a predominance of gravel, sands, and conglomerates with lime-clay matrix, although intercalations of pyroclastic and tuff layers can be distinguished.
The clastic materials rest on a base of consolidated volcanic matter of a variable nature, predominantly basalt and andesite (Unitecnia, 1996). These basalts and andesites represent a continuation of the volcanic deposits that form the mountain ranges and make up the fractured aquifers whose main function is to recharge the Valley of Toluca aquifer.

The hydraulic parameters of the aquifer of the Valley of Toluca cover a wide range of values, due to the lithological and geometric variability of the deposits. However, it is possible to differentiate areas with a transmissivity function: the area corresponding to the foot of the mountain Sierra de Las Cruces (NE), with values that reach up to $13,000 \mathrm{~m}^{2} /$ day, the Lerma sector (S) with a mean transmissivity of $950 \mathrm{~m}^{2} /$ day, the area of Almoloya del Rio (SE) with values around 22,000 $\mathrm{m}^{2} /$ day and the central section with a transmissivity that varies between 90 and $400 \mathrm{~m}^{2} /$ day. The storage coefficient fluctuates between 0.3 and $0.9 \%$ (CCRECEL 1993).

The system is made up of various levels of superimposed aquifers that come together to make up a mul- 


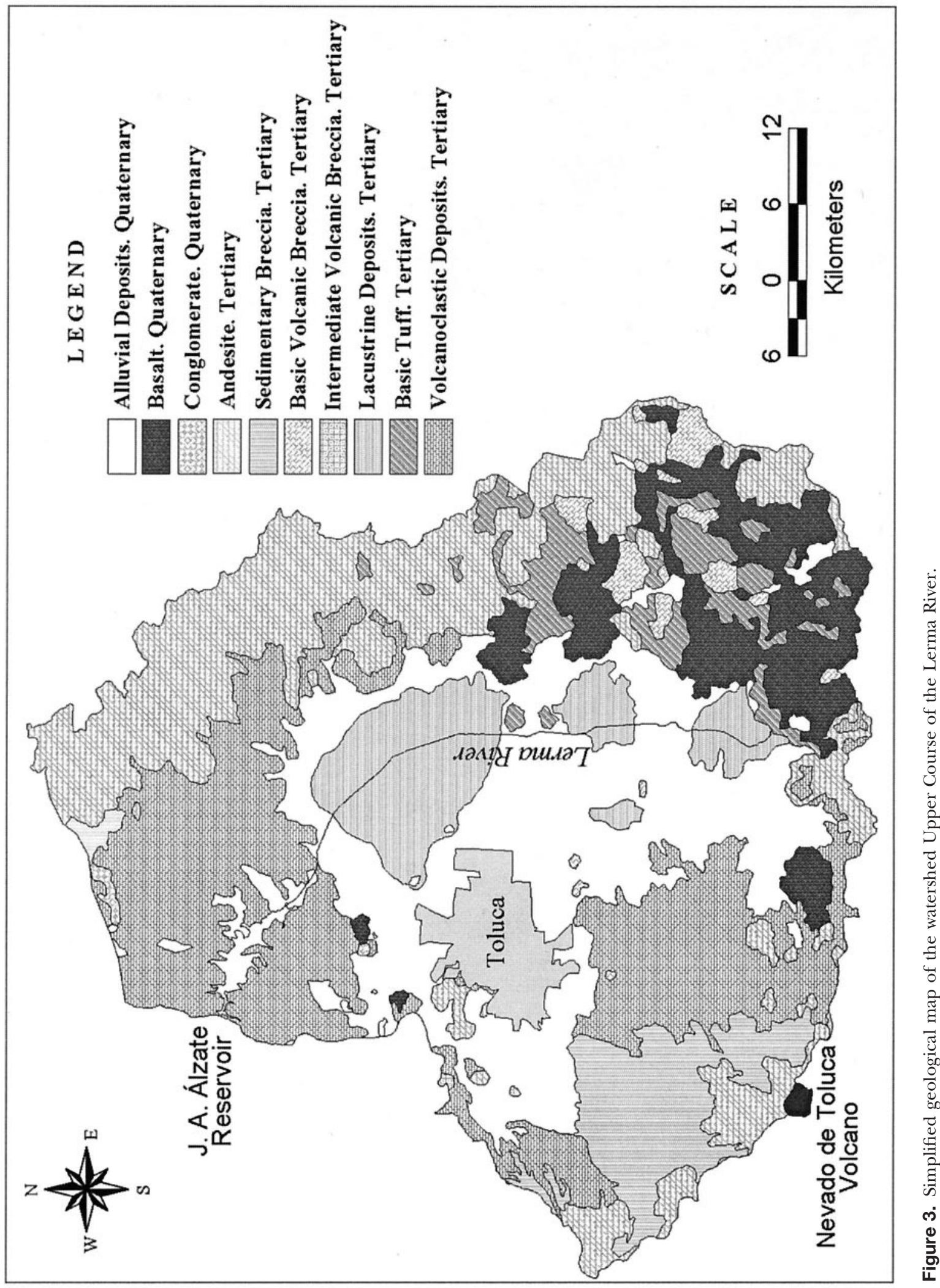


Table 1 Physiografic characteristics of the watershed of the Upper Course of the Lerma River

\begin{tabular}{|c|c|c|}
\hline \multicolumn{2}{|c|}{ Upper Course of the Lerma River watershed } & Comments \\
\hline $\begin{array}{l}\text { Surface and } \\
\text { perimeter }\end{array}$ & $\begin{array}{r}S=2117.88 \mathrm{~km}^{2} \\
P=241.79 \mathrm{~km}\end{array}$ & $\begin{array}{l}\text { The surface }(S) \text { and perimeter }(P) \text { of the watershed was } \\
\text { obtained under the use of GIS and DEM. }\end{array}$ \\
\hline $\begin{array}{l}\text { Coefficient of } \\
\text { compactness }\end{array}$ & $K_{\mathrm{c}}=1.481$ & $\begin{array}{l}\text { The obtained value of compactness coefficient indicates that } \\
\text { the river watershed tends to a square. }\end{array}$ \\
\hline Circularity ratio & $R_{\mathrm{ci}}=0.455$ & $\begin{array}{l}\text { This coefficient corroborates the proximity of the form of } \\
\text { the watershed with a square. }\end{array}$ \\
\hline Length ratio & $R_{\mathrm{e}}=1.07$ & $\begin{array}{l}\text { In agreement with the obtained value it is inferred that the } \\
\text { watershed is predominantly flat but with portions with } \\
\text { important slopes values. }\end{array}$ \\
\hline $\begin{array}{l}\text { Hypsometric } \\
\text { curve }\end{array}$ & $\begin{array}{c}H_{\max }=4,549 \text { masl } \\
H=2,848 \text { masl } \\
H_{\min }=2,556 \text { masl }\end{array}$ & $\begin{array}{l}\text { From this analysis the maximum }\left(H_{\max }\right) \text {, minimum }\left(H_{\min }\right) \\
\text { and average }(\bar{H}) \text { altitude of the watershed were obtained. } \\
\text { In agreement with the form of the hypsometric curve it is } \\
\text { inferred that the watershed is an eroded one and could } \\
\text { be classified as a valley. }\end{array}$ \\
\hline Watershed slope & $\begin{array}{l}\bar{m}=8.54 \% \\
m_{\min }=0.00 \% \\
m_{\max }=50.00 \%\end{array}$ & $\begin{array}{l}\text { The average }(\bar{m}) \text {, minimum }\left(m_{\min }\right) \text { and maximum }\left(m_{\max }\right) \\
\text { watershed slopes were obtained. The analysis of slope } \\
\text { ranks inferred that the } 52.52 \% \text { of surface is classified as } \\
\text { flat with smooth slopes, the } 30.15 \% \text { as smooth to medium } \\
\text { sloped, } 11.33 \% \text { is strongly sloped and } 8 \% \text { as steep land. }\end{array}$ \\
\hline $\begin{array}{l}\text { Drainage } \\
\text { characteristics } \\
\text { of the } \\
\text { watershed }\end{array}$ & $\begin{array}{l}\quad \overline{R b}=4.36 \\
\text { River order: } 5 \\
\text { (Horton-Strahler) }\end{array}$ & $\begin{array}{l}\text { The value of the average ratio of bifurcation }(\overline{R b}) \text { of the } \\
\text { channels is } 4.36 \text {. With this value of bifurcation, it is said } \\
\text { that the geologic structure of the watershed does not } \\
\text { distort the drainage model. }\end{array}$ \\
\hline $\begin{array}{l}\text { Main river } \\
\text { characteristics }\end{array}$ & $\begin{array}{l}L=50.2 \mathrm{~km} \\
S_{\text {river }}=0.11 \% \\
\quad S_{\mathrm{h}}=1.16\end{array}$ & $\begin{array}{l}\text { In the case of the Upper Course of the Lerma River, from } \\
\text { its origin to the Alzate dam, the river has a length of } 50.2 \\
\mathrm{~km} \text { and an average slope of } 0.11 \% \text {. The river presents a } \\
\text { hydraulic sinuosity of } 1.16 \text {. Since the value of the } \\
\text { hydraulic sinuosity is little than } 1.25 \text { and that length of } \\
\text { the reach is greater than ten times the cross section of } \\
\text { the channel, is said to be in a straight river. }\end{array}$ \\
\hline
\end{tabular}

tilayer aquifer, but the existence of a certain hydraulic continuity allows one to consider a single-flow system. Nevertheless, there are significant differences in hydraulic charge.

The hydraulic balance (Figure 5) that has been established for the aquifer defines some total inflow of $380 \mathrm{hm}^{3} / \mathrm{yr}$, of which $101 \mathrm{hm}^{3} / \mathrm{yr}$ come from lateral recharge from the Nevado de Toluca, $198 \mathrm{hm}^{3} / \mathrm{yr}$ come from lateral recharge from the Sierra de Las Cruces, and $81 \mathrm{hm}^{3} / \mathrm{yr}$ from direct infiltration of precipitation. The outflow of the system is estimated at 385 $\mathrm{hm}^{3} / \mathrm{yr}$; this discharge is produced by lateral flow towards the Valley of Ixtlahuaca-Atlacomulco, with a value of $2 \mathrm{hm}^{3} / \mathrm{yr}$, and through pumping, which is estimated at $383 \mathrm{hm}^{3} / \mathrm{yr}$. The overall balance of the aquifer indicates an imbalance between inflow and out-

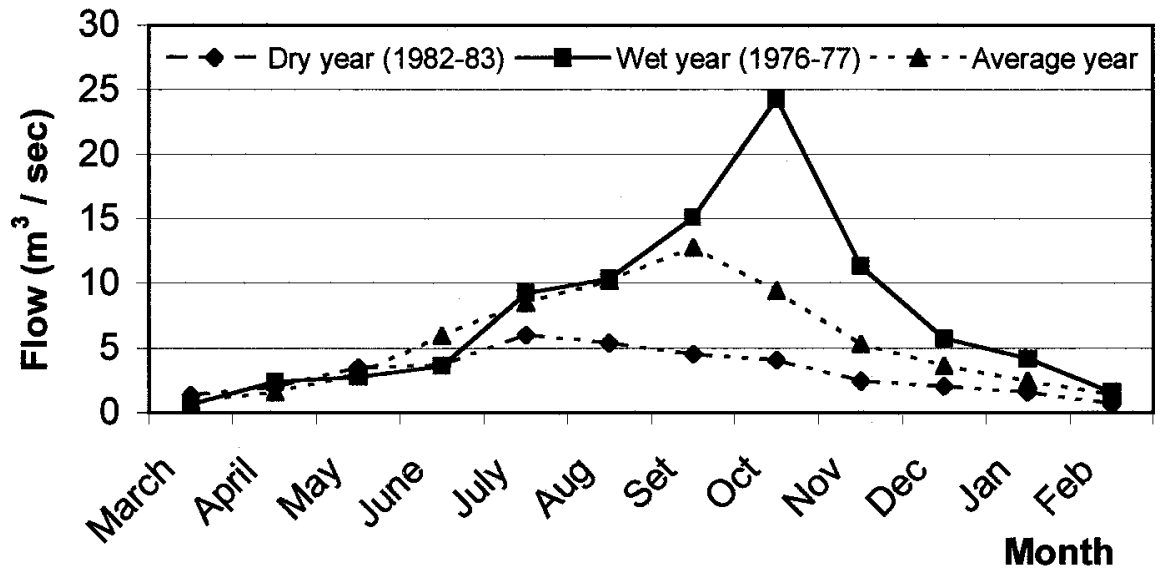

Figure 4. Interannual hydrograh estimated for the whole watershed of the Upper Course of the Lerma River. Dry year, wet year, and average year. 


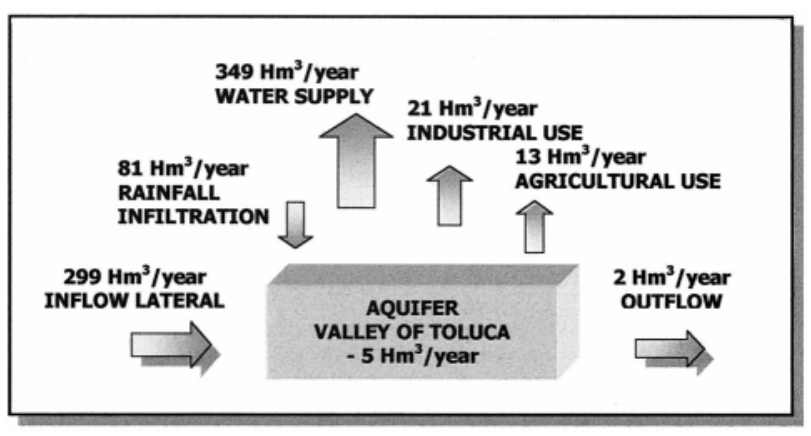

Figure 5. Diagram of the hydraulic balance.

flow, since the outflow is greater than the inflow by 5 $\mathrm{hm}^{3} / \mathrm{yr}$ (CCRECRL 1993).

From the total extracted volume, $163 \mathrm{hm}^{3} / \mathrm{yr}$ is used in the same Valley of Toluca, $79 \%$ for urban water supply, $12.9 \%$ going to industrial use, and $8.1 \%$ used for agricultural activities. Moreover, Mexico City receives $220 \mathrm{hm}^{3} / \mathrm{yr}$ from this aquifer to cover some of its potable water needs.

The wetland, made up of the Lagoons of Almoloya del Rio, originates from a series of springs located in the contact zone between the fractured volcanic deposits that form in the mountainous rims of the valley, and the quaternary clastic material that makes up the topmost levels of the valley. These lagoons, in turn, give rise to the Lerma River. The springs are located at different points, but it is at Almoloya del Rio where the greatest concentration is found: up to 262 have been counted (Romero 1991). There is also surface runoff coming from small streams located along the watershed.

\section{Results and Discussion}

\section{History of Hydraulic Resource Exploitation in the Valley of Toluca}

The desiccation process of the wetland began as a way to control flooding and to free land for agricultural purposes. A first step was taken in 1757 , but was not very successful. The subsequent works were developed from 1857 to 1870 , with deepening and widening the outflow section of the Lerma River to drain the wetland area.

Several hydraulic infrastructure works were carried out, ending in the 1950 s, to store the water in three reservoirs (Figure 1). The first reservoir, known as the Almoloya del Rio, Atenco, Chignahuapan, Agua Blanca, or Almoloyita lagoon, covered an area of about $50 \mathrm{~km}^{2}$, the second reservoir, Chimaliapan or Tlaltizapan lagoon, had a surface area of $25 \mathrm{~km}^{2}$, and the third and last reservoir, called Lerma or San Bartolo lagoon, covered an area of $10 \mathrm{~km}^{2}$ and was located in the municipalities of Lerma and Toluca (Albores 1995).

In the 1940 s and $1950 \mathrm{~s}$, a series of projects were begun to hold the spring water that recharges the Lagoons of the Almoloya del Rio and in this way the Lerma River. One of these was the digging of several galleries, connected to a drain that caught the spring water. Other projects consisted of installing wells on the eastern rim of the lagoons, which started working in 1953. All of this implied exploitation of a volume of between 3.5 and $4.0 \mathrm{~m}^{3} / \mathrm{sec}$. The water thus obtained flowed to Mexico City through an aqueduct that passed through the Sierra de las Cruces.

Later, the prevention of loss through evaporation was added to the initial goal of flood control and freeing land for agriculture, since in a study carried out at the request of the Government of the Federal District of Mexico City in 1958, the recommendation of "reducing the piezometric level between 5 and 6 meters to avoid loss through evaporation, estimated at 90-150 $\mathrm{hm}^{3}$ /year" was pointed out (CCRECRL 1997).

On the other hand, around 1940, construction of the so-called Toluca-Lerma industrial corridor was begun, where intensive industrial activity was and still is being developed. This activity can be seen in the industrial production of the State of Mexico, which has occupied one of the top places in the country from 1949 to the present. This industrial activity carries with it an increase in population density in the valley, which in turn increases both industrial and urban water needs which were met by drilling wells throughout the whole valley.

The critical evolution of the water availability resulted in a presidential decree, on 10 August 1965 establishing a restriction on the use of this aquifer, but, in that same year, the demand for water in Mexico City could not be met, and an agreement was signed between the Government of the Federal District of Mexico City, the Secretariat of Hydraulic Resources, and the Government of the State of Mexico (1966-1969). This agreement allows the increased extraction from the Lerma River area, invalidating the presidential decree (Boehm and Sandoval 1999). After this agreement, the aquifer of the Valley of Toluca was under a restrictive ban, which means that no new wells can be built.

Based on this agreement, in 1970, the drilling of over 100 wells and an aqueduct of $170 \mathrm{~km}$ to transport water from the Valley of Toluca to Mexico City was concluded. Some of these wells are found located exactly in the transition area between the wetland and the mountain border.

The last works built were in the first lagoon, the Almoloya Lagoon, based on the construction of two 


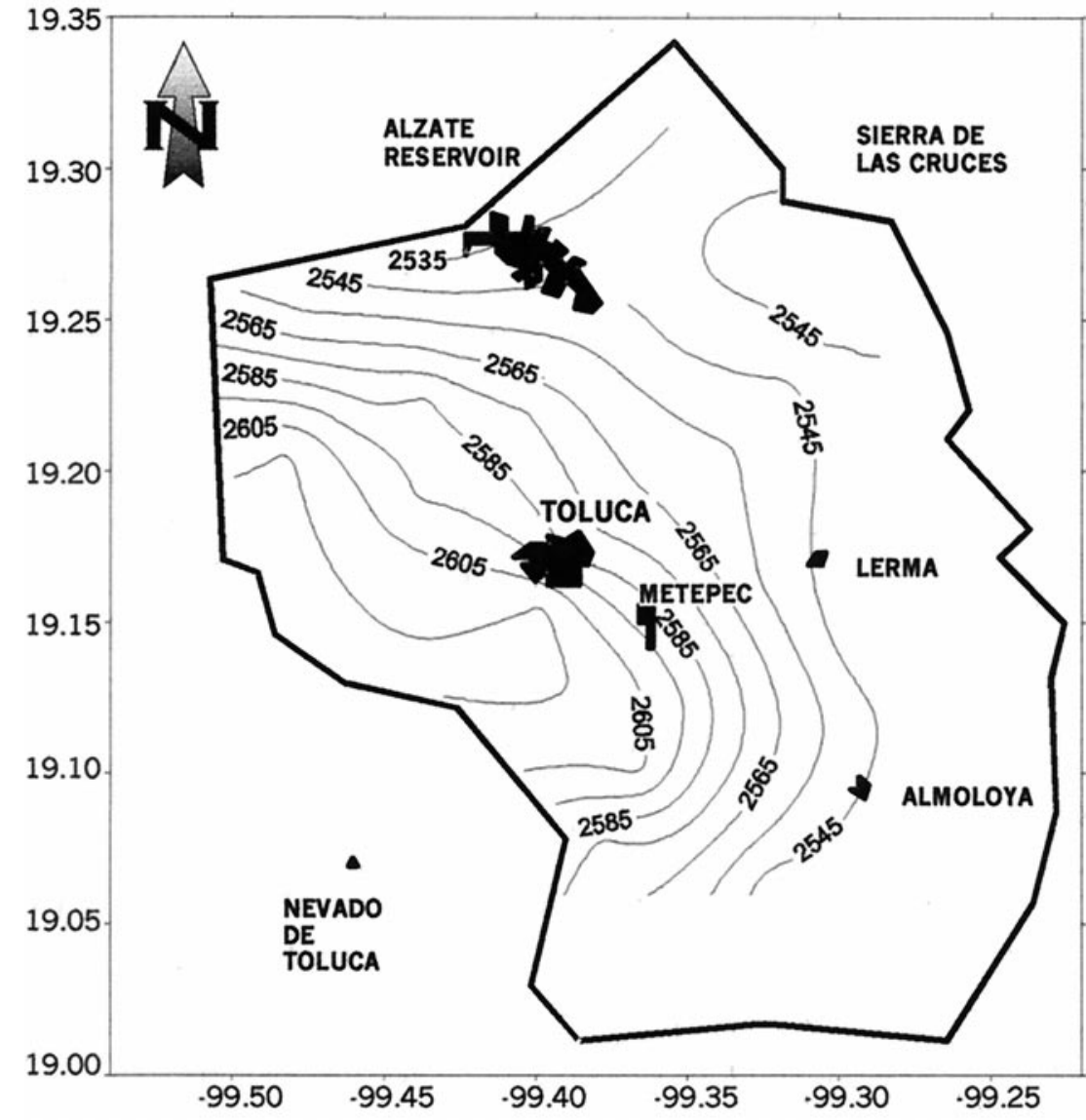

Figure 6. Water table map for October-November 1996 (in meters above sea level, contour interval $10 \mathrm{~m}$ ). reservoirs within the lagoon. One reservoir is the CUMAC, built in 1975, with Canadian financing meant to help preserve the ecosystem, and the outer reservoir, which encompasses the first, was begun in 1991; $8 \mathrm{~km}$ have been built, leaving $1.8 \mathrm{~km}$ still to be constructed. These works and other canal works are being carried out by the Secretariat of Agricultural Development of the State of Mexico (SEDAGRO). The purpose of this latter reservoir and the canal works is to reduce the flood area to a defined surface, to allow for the cultivation of lands and exploit rain water to store irrigation in the dry season (Díez-Perez 1998).

\section{Piezometric Evolution}

On the piezometric map, corresponding to the period of October-December 1996 (Figure 6), it can be seen that the main recharge comes from the Nevado de Toluca and that the circulation of groundwater is towards the center of the valley, being distributed in three directions, towards SE and E to the foot of the Sierra de Las Cruces, and towards $\mathbf{N}$ in the direction of the Valley of Atlacomulco-Ixtlahuaca. The main characteristic that can be observed is the influence of the set of wells installed at the foot of the Sierra de Las Cruces to withdraw water for use in Mexico City, which means that the volume coming from the Sierra de las Cruces towards the valley has been intercepted by these wells, neutralizing their influence of recharge towards the internal area of the valley.

The exploitation process of groundwater is reflected in the map of equal decline contour lines between 1971 and 1996 (Figure 7). A piezometric depression cone in the area of Toluca City, with a maximum reduction rate of $3.5 \mathrm{~m} / \mathrm{yr}$, can be seen from this map. In the case of the area that covers the wetland, the map shows that the decreases have not been so important, but they have been hydraulically and ecologically significant. With relation to this important piezometric decline, the appearance of cracks and differential collapses in the land can be seen in different areas of Toluca City, causing damage to housing and roadways. These subsidence structures can be put into two different groups according to their direction- $-\mathrm{N}-\mathrm{S}$ and $\mathrm{SE}-\mathrm{NE}$ - with variable vertical displacements, going from a few centimeters up to half a meter, and an average length of $500 \mathrm{~m}$. The first effects of this subsidence on the land were detected 
Figure 7. Map of equal decline contour lines between 1971 and 1996 (in meters, contour interval 5 meters).

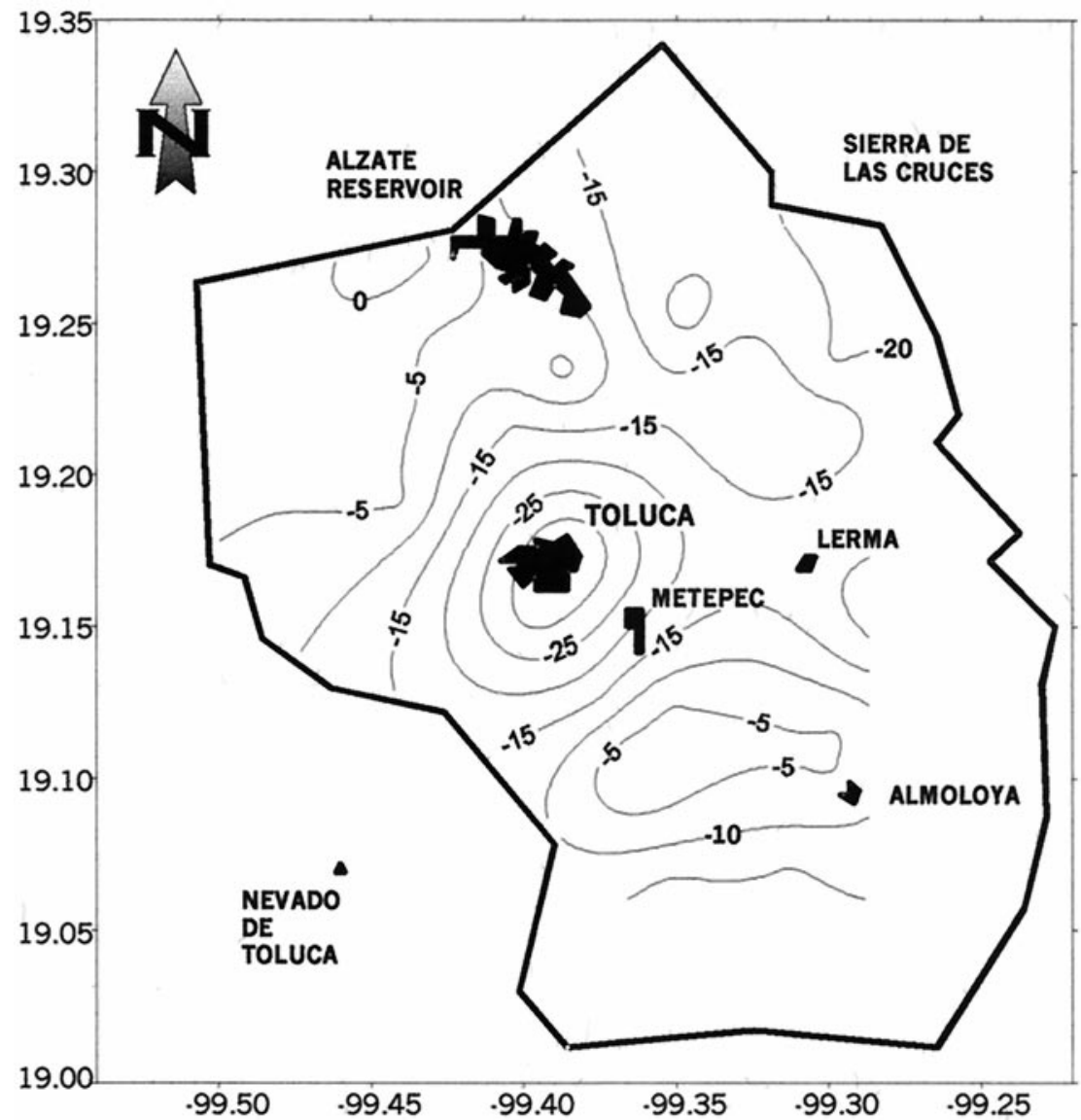

in 1985 and currently continue, although they do not seem to be that important, as the rate of subsidence is at most between 2 and $3 \mathrm{~mm} / \mathrm{yr}$.

To carry out the study of evolution over time of the piezometric level in the wetland zone, four observation wells were chosen, belonging to the monitoring network that exists in the aquifer (Figure 1). Figure 8 shows the evolution of the piezometric level at these points for the period between 1968 and 1996. A gradual decline of the piezometric level can clearly be seen due to the effect of pumping groundwater and a decrease in the discharge of the springs, which are a source of recharge of the aquifer. In the case of observation well pl145, located in the area around the first lagoon (Almoloya Lagoon), stabilization of the level starting in the 1980 s can be seen. This stabilization of the piezometric level is related to the construction of the CUMAC reservoir, which has allowed some recharge of the aquifer. In other zones of the aquifer, the piezometic level continues declining, with no stabilization of the level.

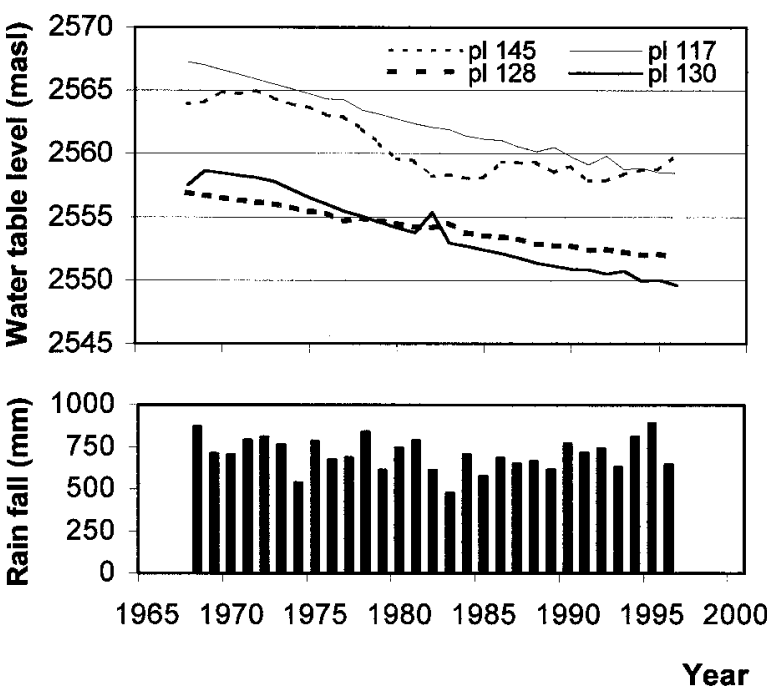

Figure 8. Water table hydrographs. Observation wells are shown in Figure 1. 


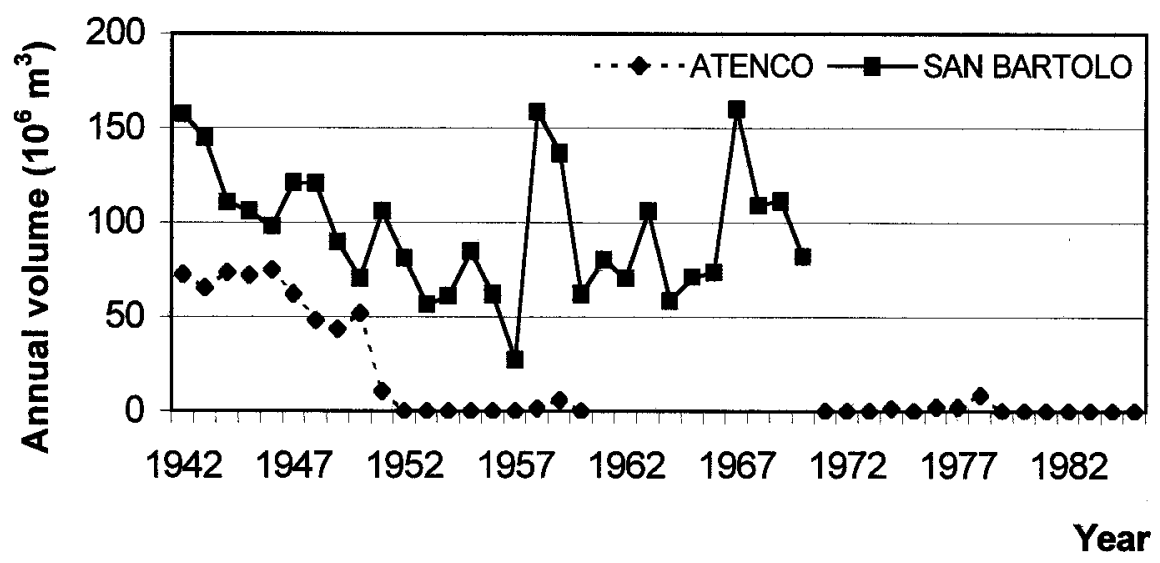

Figure 9. Evolution of water flow in Atenco and San Bartolo hydrometric gauge stations.

Table 2 Evolution of surface area of reservoirs of the wetlands of the Lagoons of the Almoloya del Rio ( $\left.\mathrm{km}^{2}\right)$

\begin{tabular}{|c|c|c|c|c|c|}
\hline & \multirow[b]{2}{*}{$\begin{array}{c}\text { SRH } \\
(1969)\end{array}$} & \multirow[b]{2}{*}{$\begin{array}{l}\text { Albores (1995) } \\
\text { Data 1960-1970 }\end{array}$} & \multicolumn{2}{|c|}{ IPESA (1984) } & \multirow[b]{2}{*}{$\begin{array}{l}\text { SARH } \\
(1986)\end{array}$} \\
\hline & & & $\begin{array}{l}\text { Wet } \\
\text { period }\end{array}$ & $\begin{array}{l}\text { Dry } \\
\text { period }\end{array}$ & \\
\hline Almoloya Lagoon & 29 & 50 & 33 & 0.2 & 32 \\
\hline Tlaltizapan Lagoon & 40 & 25 & 19 & 0.1 & 26 \\
\hline San Bartolo Lagoon & 32 & 10 & 34 & 0.3 & 25 \\
\hline Total & 101 & 85 & 86 & 0.6 & 83 \\
\hline
\end{tabular}

\section{Evolution of Surface Water Flow}

As mentioned above, the three lagoons of Almoloya are primarily recharged by the water coming from springs and surface runoff. To establish the circulation between the lagoons and their outflow, the authorities installed two hydrometric gauge stations (Figure 1). The Atenco station is located between the first two lagoons and has recorded from 1942 to 1985 (although there are no data from 1961 to 1970). The San Bartolo station is located at the outflow of the third lagoon, which is considered the source of the Lerma River, and the recording period began in 1942 and ended in 1970.

It can be also seen in Figure 9, with respect to the Atenco hydrometric gauge station, that in the last decades recorded, the circulation of water between the first two lagoons was only occasional, due to the effect of the hydraulic works as well as the dam built above the Atenco hydrometric gauge station. The reservoir was put into use in April 1951, and at times, wood pieces were added to exploit water at higher levels than the concrete dam, which is $0.9 \mathrm{~m}$ high (crest elevation $2574.43 \mathrm{~m}$ asl).

In the case of the San Bartolo hydrometric gauge station, the decrease in flow throughout the 1950s was very significant, but later the decrease has not been as marked, as the lagoon and river were receiving important amounts of surface water and wastewater.
The study of the evolution of the flows of the abovementioned two stations reflects the effect of the works that were carried out to export water to Mexico City, as well as the works for storing water from the lagoons. The hydraulic infrastructure installed modified the process of the inflow of water to these lagoons, which is why today one can consider the only source of inflow for the wetland area to be the surface-water runoff.

\section{Decrease of Wetland Surface Area}

The processes and strategies of hydraulic resource exploitation of the basin have caused a reduction in the surface area of the wetland over the years (Table 2), since the volume of water brought in from the springs has decreased and there has been a generalized decrease in the piezometric level. An example of this decrease is the Almoloya Lagoon (Figure 10), which has gone from a surface area of $23.9 \mathrm{~km}^{2}$ in 1970 to 7.8 $\mathrm{km}^{2}$ in 1989, although in the 1990s some of the area was recovered because of the building of the reservoirs, and therefore in 1995 this lagoon covered an area of 10.3 $\mathrm{km}^{2}$.

Other proof of the consequences of the drying process of the wetland is that before it started there were small islands, such as the Mirafuentes (Almoloya del Rio) and temporary islands (in the rainy season), such as San Antonio La Isla, San Juan La Isla, and San Pedro 


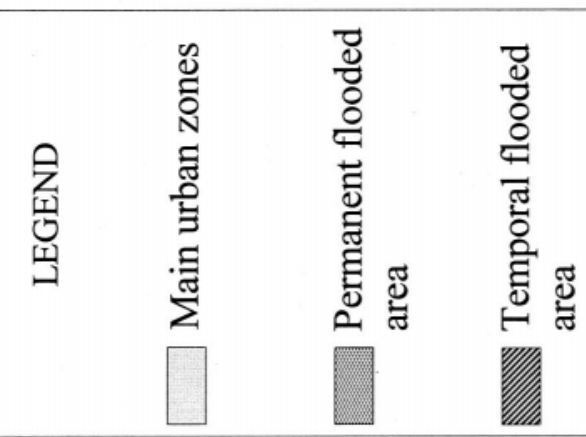

焉焉薯

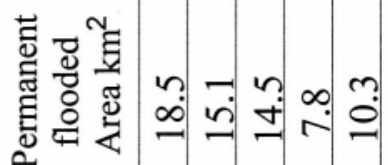
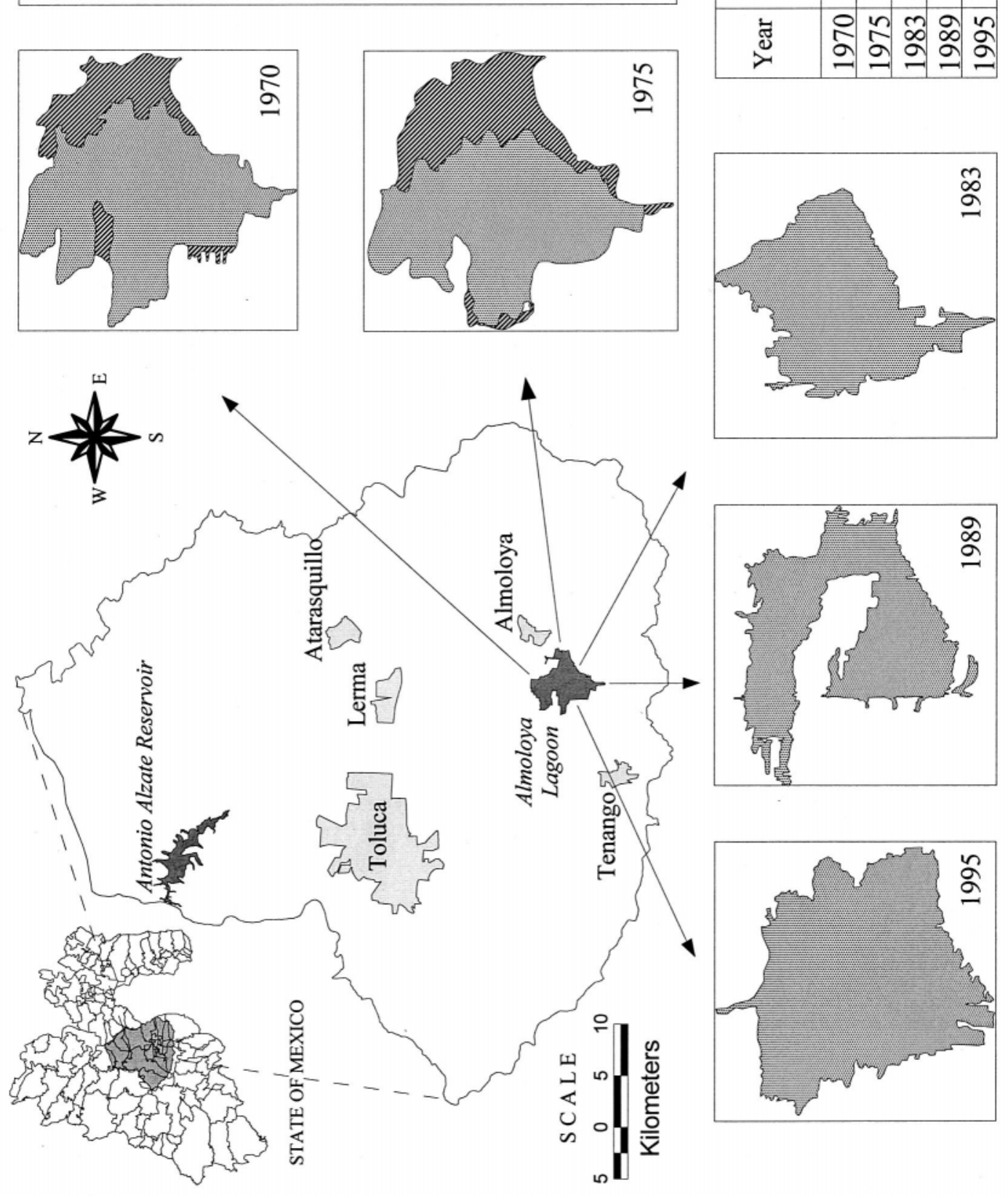
Tultepec de Quiroga La Isla, thus the origin of their names (Albores 1995). At the present time, these islands are surrounded by agricultural lands.

\section{Water Quality}

The water quality of the lagoons and that of the Lerma River has been deteriorating over time as a result of the inflow of both urban and industrial wastewater, which has combined with the effect of a decrease in water volume. This reduction in freshwater volume and the deterioration of the water quality has resulted in an important decrease in lake, fluvial, and riparian life in the region.

An example of this can be seen in a $25-\mathrm{km}$ reach of the Lerma River between the Alzate Dam and the Toluca-Mexico Highway, where there is no dissolved oxygen present in the months from November to May, when the river flow is low and the organic charge levels are high [biochemical oxygen demand (BOD) of 248 $\mathrm{mg}$ /liter of $\mathrm{O}_{2}$ ]. During the rest of the year, the values of dissolved oxygen are less than $2 \mathrm{mg}$ /liter (Garrido and García-Aragón 1997).

Within the Ecological Recovery Plan for the Lerma River, developed by the Coordinating Commission for the Ecological Recovery of the Lerma River Basin of the Government of the State of Mexico and the National Program for Basin Improvement of the Federal Government, actions to widen the drainage infrastructure and the wastewater treatment were set forth and have been carried out over the past few years. The impact of these actions has resulted in some recovery of the Lerma River as an improvement in water quality of the river water has been reported (Castillo-Escalante 2000).

On the other hand, with respect to groundwater, an increase in salinity (electrical conductance increase from about $297 \mu \mathrm{S} / \mathrm{cm}$ in 1993 to about $978 \mu \mathrm{S} / \mathrm{cm}$ in 1998) and an increase in the concentration of heavy metals, such as Fe (from 0.1 to $2.51 \mathrm{mg} /$ liter) and $\mathrm{Mn}$ (from 0.13 to $0.22 \mathrm{mg} /$ liter), which are above the allowed levels for drinking water according to Mexican standards, have been seen (Esteller and others 1999). This increase in the mineralization of the groundwater could be related to the extraction of regional groundwater with a longer period of residence, since as the piezometric level decreases, an incorporation of deeper groundwater is taking place.

\section{Conclusions}

The overexploitation of the Valley of Toluca aquifer is related to the industrialization process that began in the 1940s and which has affected both the Valley of Toluca and the Valley of Mexico. This process implied a greater demand for water to cover both the industrial and drinking water needs, demands that grew as the population of the valleys grew.

This overexploitation has resulted in a drawdown of the piezometric level of the aquifer, at an average rate of $1.4 \mathrm{~m} / \mathrm{yr}$ and an maximum of $3.5 \mathrm{~m} / \mathrm{yr}$, the emergence of cracks over the land surface due to subsidence, a decrease in the volume of the Lerma River, and a reduction in the wetland surface area.

The deterioration of the wetland of Almoloya del Rio is directly related to the works to exploit the springs that recharge the lagoons, works that were carried out to supply drinking water to Mexico City. This deterioration has had a huge environmental impact as it has produced a slow, but steady drying process of the lagoons, which has affected the flora and fauna of the area, as well as the use of the land, as the drained lands were used for agricultural purposes.

The steps taken up to now to mitigate the effects of overexploitation of the aquifer have not resulted in the recovery of the aquifer, making it necessary to seek other means within the framework of integrated watershed management, bearing in mind both the surface water and groundwater, as well as the reuse of treated waste water. For example, turning the exploitation of water from wells to other sources (superficial water, treated wastewater), reducing the pumping rate (Martinelli and others 1998) and artificial recharge and restoration of wetland with treated waste water (White and Bayley 1999).

\section{Acknowledgments}

This study has been financially supported by the Mexican National Research Council CONACyT (Mexico), under the projects 0391 and 0389 , and by the Universidad Autonoma del Estado de Mexico. The authors are grateful to all referees, who have contributed with their comments to the improvement of this paper. Special thanks also to Dr. Alin Carsteânu, who did the final English corrections.

\section{Literature Cited}

Albores, B. A. 1995. Tules y Sirenas. El impacto ecológico y cultural de la industrialización en el Alto Lerma. El Colegio Mexiquense y Gobiemo del Estado de México. México, 478 pp.

Boehm, B., and M. Sandoval. 1999. La sed saciada de la Ciudad de México y la nueva cuenca Lerma-Chapala-Santiago. Un ensayo metodológico de lectura cartográfica. Relaciones, Estudios de Historia y Sociedad 20(80):15-68.

Castillo-Escalante, I. 2000. El saneamiento y la calidad del 
agua. Tláloc-Revista de la Asociación Mexicana de Hidráulica 18:4-9.

CCRECRL (Comisión Coordinadora para la Recuperación Ecológica de la Cuenca del Rio Lerma). 1993. Atlas Ecológico de la Cuenca Hidrográfica del Río Lerma. Tomo I. Cartografía. Gobierno del Estado de México, México, 414 pp.

CCRECRL (Comisión Coordinadora para la Recuperación Ecológica de la Cuenca del Rio Lerma). 1997. Atlas Ecológico de la Cuenca Hidrográfica del Rio Lerma. Tomo III. Atlas de Ecosistemas Productivos. Gobierno del Estado de México, México, 256 pp.

Celik, M., and M. Afşin. 1998. The role of hydrogeology in solution-sunsidence development and its environmental impacts; a case-study for Sazlica (Nigde, Turkey). Environmental Geology 36(3-4):335-342.

Cruickshank, G. 1995. Proyecto Lago Texcoco: Rescate Hidroecológico. Comisión Nacional del Agua. Gobierno de la Ciudad de México, México. 111 pp.

Deman, M. S. 1976. El Eje Neovolcánico Transmexicano. In Procedeedings of the Congreso Latinoamericano de Geologia. Instituto de Geologia, UNAM, México, 6 pp.

Diez-Perez, A. 1998. Análisis de las zonas de recarga de acuíferos mediante la percepción remota: Aplicación a la Cuenca de Almoloya del Rio. Masters thesis. Universidad Autónoma del Estado de México, México, 156 pp.

Esteller, M. V., C. Diaz-Delgado, and K. M. Bâ. 1999. Presencia de hierro y manganeso en el acuífero del Valle de Toluca. Pages 10-11 in Proceedings of the IV Congreso Nacional de Ciencias Ambientales, 26-28 May 1999. Toluca, Mexico.

Garrido, S., and J. A. Garcia-Aragón. 1997. Alternativas ecohidráulicas para la presa José Antonio Alzate con base en el comportamiento de sus parámetros de contaminación. Ciencia Ergo Sum 4(3):305-309.

Herrera, M. E., and J. L. Sánchez Zavala. 1994. Estratificación y Recursos Minerales del Estado de México. Memoria y mapas. Gobierno del Estado de México. Secretaria de Desarrollo Económico. México.

Honorio, R. J., and H. F. Hernández. 1982. Origen, Estratigrafía y Petrología de la Cuenca de México y Sierras Circunvecinas. Thesis professional. Instituto Politécnico Nacional, México.

IGECEM (Instituto Cartográfico, Estadistico y Catastratal del Estado de Mexico). 1995. Orthophotos IGECEM. Scale 1:20,000 (orthophotos 87, 88, 89, 90, 91, 108, 419, 110, 118, 119 and 120) flight 1983, 1989 and 1995. Gobierno del Estado de México, México.
IPESA. 1983. Rehabilitación de la Laguna de Almoloya. Estado de México. Technical report. Secretaria de Desarrollo Agropecuario (SEDAGRO). Gobierno del Estado de México, México.

Llamas, M. R. 1992. Wetlands: an important issue in Hydrogeology. Pages 69-86 in I. Simmers, F. Villarroya and L. F. Rebollo (eds.), Selected papers on aquifer overexploitation. Verlang Heinz Heisa, Hannover, Germany.

Martinelli, G., A. Minessale, and C. Varrucshi. 1998. Geochemistry of heavily exploited aquifers in the EmiliaRomagna Region (Po Valley, Northern Italy). Environmental Geology 36(3-4):195-206.

Martinez-Alfaro, P. E., E. Montero-Gonzalez, and B. LópezCamacho. 1992. The impact of the overexploitation of the Campo de Montiel aquifer on the Lagunas de Ruidera Ecosystem. Pages 87-92 in I. Simmers, F. Villarroya, and L. F. Rebollo (eds.), Selected papers on aquifer overexploitation. Verlang Heinz Heisa, Hannover, Germany.

Miller, A. A. 1982 Climatología, 5th ed. Ediciones Omega, Barcelona, España, 379 pp.

Rodriguez-Estrella, T., and F. Lopez-Bermudez. 1992. Some ecological consequences of aquifer overexploitation in wetlands in Spain. Pages 93-106 in I. Simmers, F. Villarroya, and L. F. Rebollo (eds.), Selected papers on aquifer overexploitation. Verlang Heinz Heisa, Hannover, Germany.

Romero, P. 1991. Historia de las obras de abstecimeinto de agua y drenaje de la Ciudad de Mexico y su impacto socioambiental. Masters thesis. Universidad Nacional Autónoma de México, México, 120 pp.

SARH (Secretaria de Agricultura y Recursos Hidráulicos). 1986. Planos de la Residencia General de Administración y Control de Sistemas Hidrológicos. Gobierno de México, Mexico.

Scott, M. L., P. B. Shafroth, and G. T. Auble. 1999. Responses of Riparian cottonwoods to alluvial water table decline. Environmental Management 23:347-358.

SRH (Secretaria de Recursos Hidráulicos). 1969. Aprovechamiento hidráulico. Pozos perforados en la Cuenca Alta del Rio Lerma. Technical report. Gobierno de México, Mexico.

Unitecnia. 1996. Estudio para el diseño de redes de monitoreo de los acuíferos de los Valles de Toluca y Atlacomulco-Ixtlahuaca, en el Estado de México. Technical report. Comisión Nacional del Agua, 66 pp.

White, J. S., and S. E. Bayley. 1999. Restoration of a Canadian Prairie wetland with agricultural and municipal wastewater. Environmental Management 24:25-37. 